\title{
Autecology of the lizard Colobosauroides cearensis (Squamata: Gymnophthalmidae) from Brazilian semiarid Caatinga
}

\author{
Aldenir Ferreira da Silva Neta, ${ }^{1}$ Cicera Silvilene Leite Matias, ${ }^{2}$ and Robson Waldemar Ávila ${ }^{3}$ \\ ${ }^{1}$ Programa de Pós-Graduação em Ciências Biológicas- PPGCB (Zoologia), Universidade Federal da Paraíba. Via Expressa \\ Padre Zé Jardim, Cidade Universitária, 58051001, João Pessoa, PB, Brazil. E-mail: aldenirferreira_@ hotmail.com. \\ ${ }^{2}$ Programa de Pós-graduação em Sistemática, Uso e Conservação da Biodiversidade, Universidade Federal do Ceará, Campus \\ Universitário do PICI, Departamento de Ciências Biológicas. Av. da Universidade, 2853, Benfica, 60021-970, Fortaleza, CE, \\ Brazil. \\ ${ }^{3}$ Programa de Pós-graduação em Ecologia e Recursos Naturais, Centro de Ciências, Universidade Federal do Ceará, Campus \\ do PICI, Bloco 209. Av. Humberto Monte s/n, 60455-760, Fortaleza, CE, Brazil.
}

\begin{abstract}
Autecology of the lizard Colobosauroides cearensis (Squamata: Gymnophthalmidae) from Brazilian semiarid Caatinga. Colobosauroides cearensis is a diurnal lizard with a relictual distribution associated with forested habitats in the Brazilian Caatinga Domain. Knowledge of the natural history of this secretive lizard is scarce. Herein, the diet, reproduction, sexual dimorphism, microhabitat use, and thermal ecology of $C$. cearensis are described based on fieldwork in 2015-2017 in the state of Ceará, Brazil. The diet of the lizards is composed exclusively of arthropods, with Formicidae being the most important prey category. Numerical and volumetric niche breadths are 5.52 and 9.2 respectively, and trophic niche overlap between females and males is 0.3. Males are distinguished from females by the larger size of the males and the presence of femoral pores. Colobosauroides cearensis is cryptozoic, inhabiting the leaf litter and having no direct contact with the soil or solar radiation. The average body temperature of the lizards is $30.4 \pm 3.3^{\circ} \mathrm{C}$, which is positively correlated with the air temperature. Gravid females with fixed clutch size of two eggs are found in early rainy season. Oviposition occurs between April and May (when the highest number of juveniles are observed). Sexual maturity occurs early in males and testicular volume is significantly correlated with body size.
\end{abstract}

Keywords: diet, habitat, reproduction, sexual dimorphism, thermoregulation.

\footnotetext{
Resumo

Autoecologia do lagarto Colobosauroides cearensis (Squamata: Gymnophthalmidae) da Caatinga semiárida brasileira. Colabosauroides cearesis é um lagarto diurno com distribuição relictual associados a habitats florestais, no domínio da Caatiga brasileira. O conhecimento da
}

Received 11 March 2019

Accepted 03 September 2019

Distributed December 2019 
história natural desse lagarto é escasso devido o seu habito secreto. Aqui, descrevemos a dieta, reprodução, dimorfismo sexual, uso de microhabitat e ecologia térmica de C. cearensis, com base em trabalhos de campo entre 2015-2017 no estado do Ceará, Brasil. A dieta desses lagartos é composta exclusivamente por artrópodes, sendo Formicidae a categoria de presas mais importante. A largura de nicho numérico e volumétrico foram 5,52 e 9,2, respectivamente, e a sobreposição de nicho trófico entre fêmeas e machos foi de 0,3 . Os machos distinguem-se das fêmeas por apresentar maior tamanho e pela presença de poros femorais. Colobosauroides cearensis é criptozóico, habitando a serapilheira e não tendo contato direto com o solo ou radiação solar. A temperatura corporal média dos lagartos é de $30,4 \pm 3,3^{\circ} \mathrm{C}$, correlacionada positivamente com a temperatura do ar. Fêmeas grávidas com tamanho de ninhada fixa de dois ovos são encontradas no início da estação chuvosa. A ovipostura ocorre entre abril e maio (quando o maior número de juvenis foi observado). A maturidade sexual ocorre cedo nos machos, e o volume testicular está significativamente correlacionado com o tamanho do corpo.

Palavras-chave: dieta, dimorfismo sexual, habitat, reprodução, termorregulação.

\section{Introduction}

To understand the dynamics of ecosystems and evolutionary history of a species, it is essential to be familiar with the autecology of the species; this includes its diet, sexual dimorphism, reproduction, microhabitat use, and thermal ecology (Dunham et al. 1988, Pianka and Vitt 2003). Such information is critical to species conservation and land-management strategies, particularly now when many taxa are being extirpated owing to anthropogenic habitat destruction (Myers 2000, Primack 2008).

Studies of population and community ecology, foraging, and life histories of lizards have contributed significantly to the formulation of ecological theories (Huey et al. 1983, Vitt and Pianka 1994, Pianka and Vitt 2003). However, Vitt and Caldwell (2013) pointed out that only $5 \%$ of squamates have adequate information about their life history, especially in the Neotropics. Most of our knowledge of ecology and population dynamics of lizards is based on temperate species, and generalizations about life-history patterns of tropical species may be erroneous given the different ecogeographic conditions (Colli et al. 2003).

Gymnophthalmidae comprises 235 species (Uetz and Hošek 2016). Gymnophthalmids are restricted to the Neotropics, and are characterized by smaller body sizes and marked plasticity in habitat use, including terrestrial, semifossorial, fossorial, semiaquatic, and semiarboreal species (Pellegrino et al. 2001). The fossorial habits of some species are reflected in their morphology by attenuation of the body, varied reduction of the limbs, and loss of eyelids and the external ear (Pellegrino et al. 2001, Rodrigues et al. 2007).

Colobosauroides cearensis Cunha, LimaVerdade, and Lima, 1991 has relictual distribution in the Caatinga of the Brazilian semiarid region associated with forest enclaves in Ceará. This includes peripheral areas of the city of Fortaleza (Cunha et al. 1991, Borges-Nojosa and Caramaschi 2003) in the state of Piauí in the Fazenda Paquetá (Silva et al. 2015), as well as an isolated population in the municipality of Mauriti in the southern state of Ceará (Silva-Neta et al. 2019). The natural history of $C$. cearensis has been unknown (Cunha et al. 1991), and it is classified as Data Deficient by IUCN criteria (IUCN 2017); this lack of knowledge curtails the development of conservation actions, especially for organisms with restricted distributions (Rocha et al. 2009). Herein, aspects of the natural history of $C$. cearensis, including diet, sexual dimorphism, microhabitat use, thermal ecology, and reproduction are described. 


\section{Materials and Methods}

\section{Study Area}

The study was conducted in the municipality of Mauriti $\left(07^{\circ} 22^{\prime} 46.08^{\prime \prime}\right.$ S, 38 38'47.87" W), state of Ceará in northeastern Brazil (Figure 1). The vegetation is primarily deciduous forest and hypoxerophytic Caatinga. The local climate is hot and semiarid, with the rainy period occurring from February-April, and the mean annual rainfall ranging from 500-800 $\mathrm{mm}$ (IPECE 2016).

A total of 116 lizards was collected by hand in visual searches in the dry season (November 2015 and December 2016) and in the rainy season (May 2016 and April 2017). Visual surveys were carried out between 08:30 h and 16:30 h, and totaled 20 days of effort. Specimens were collected with scientific collecting permit issued by ICMBio (52214-1) and authorized by ethics committee of the Universidade Regional do Cariri (CEUA/URCA process $n^{\circ}$ 00026/ 2015.2). Lizards were euthanized with a lethal injection of sodium thiopental, fixed in $10 \%$ formalin, preserved in $70 \%$ alcohol and deposited in the Herpetological Collection of the Universidade Regional do Cariri.

Diet

Stomach contents of the lizards were examined and identified to lowest taxonomic category possible, usually the ordinal level. Prey volume was estimated with the formula for an ellipsoid: $V=(4 / 3 \pi)($ length $/ 2)(\text { width } / 2)^{2}$.

The inverse of the Simpson's index of diversity was calculated to measure the numerical and volumetric food niche widths described for the microhabitat; the values vary from 1 (use only one prey category) to $N$ (equal use of all prey categories).

To determine the relative contribution of each prey category, we calculated the relative importance index $(I)$ using: $I=F \%+N \%+\mathrm{V} \%$, where $\mathrm{F} \%, \mathrm{~N} \%$ and $\mathrm{V} \%$ are the percentages of frequency, number, and volume of prey categories
(Powell et al. 1990). The food niche overlap between the males and females was assessed with Pianka's overlap index (Pianka 1973) in Ecosim 7.0 software (Gotelli and Entsminger 2004): /.

To access intersexual similarity in diet we performed a Principal Coordinate Analysis (PCoA) (Torgerson 1958, Gower 1966) with Bray-Curtis distance.

\section{Sexual Dimorphism}

The following measurements $( \pm 0.01 \mathrm{~mm})$ were recorded with digital calipers for each adult lizard: snout-vent length (SVL); tail length (TL); body width (BW); body height $(\mathrm{BH})$; head width (HW); head height (HH) and length (HL); jaw length (JL); forearm length (FL); and hindlimb length (HI). To sexual dimorphism in SVL, we conducted a Student's $t$-test. The residuals from a multiple regression between each variable and SVL were used to remove the effect of body size in the analysis of sexual dimorphism. A principal component analysis (PCA) was performed using all residuals from morphometric variables except SVL and TL. Also, a permutational multivariate analysis of variance was performed to access sexual size dimorphism.

\section{Microhabitat Use}

Spatial niche breadth $(B)$ was evaluated with the reciprocal of the Simpson Diversity Index: , where $i$ is the microhabitat category, $P$ is the proportion of $i$, and $N$ is the number of categories. The value of $B$ varies from 1 (use one microhabitat category) to $N$ (equal use of all microhabitat categories). Spatial niche overlap between the males and females was calculated with Pianka's overlap index (presented above).

\section{Thermal Ecology}

The cloacal temperature $\left(\mathrm{T}_{c}\right)$ of the lizards was measured with a cloacal thermometer (Miller \& Weber Inc., accuracy of $0.2^{\circ} \mathrm{C}$ ) within $15 \mathrm{~s}$ of capture of individuals that had run no farther than 


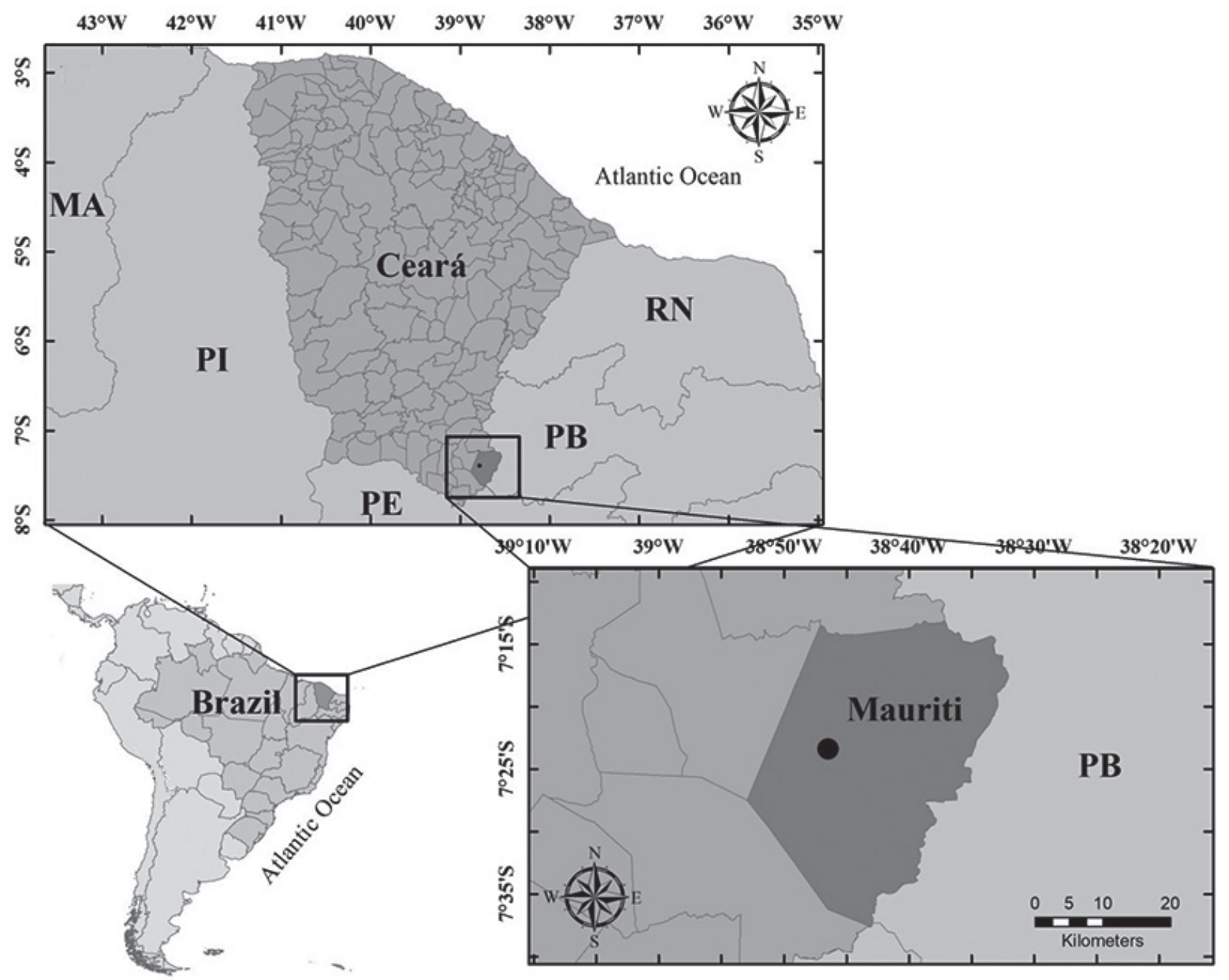

Figure 1. Map of the study site (black circle) in the municipality of Mauriti, Ceará state, northeastern Brazil.

$50 \mathrm{~cm}$ before being captured. Substrate temperature $\left(\mathrm{T}_{\mathrm{s}}\right)$ and air temperature $\left(\mathrm{T}_{\mathrm{a}}\right)$ were measured $5 \mathrm{~cm}$ above the soil with a precision thermometer $\left(0.2^{\circ} \mathrm{C}\right)$. We conducted a multiple regression analysis to evaluate the relationships among $\mathrm{T}_{c}, \mathrm{~T}_{\mathrm{a}}$, and $\mathrm{T}_{\mathrm{s}}$. We used a Student's $t$-test to evaluate seasonal differences in cloacal temperatures, as well as intersexual differences.

\section{Reproduction}

The sex of the lizards was determined by dissection and direct examination of the gonads. Females were considered sexually mature based on appearance and size of follicles, and/or the presence of oviductal eggs and corpora lutea. Females having vitellogenic follicles and eggs in the oviduct and/or presence of corpora lutea simultaneously were determined to have more than one clutch per reproductive season. Clutch size was estimated according to the number of vitellogenic follicles or eggs present in the oviduct. Males were classified as sexually mature when convoluted epididymides and enlarged testicles were present (Ballestrin et al. 2010). We recorded lengths and widths of both testicles in males and vitellogenic follicles and eggs in females; the volumes of these structures were 


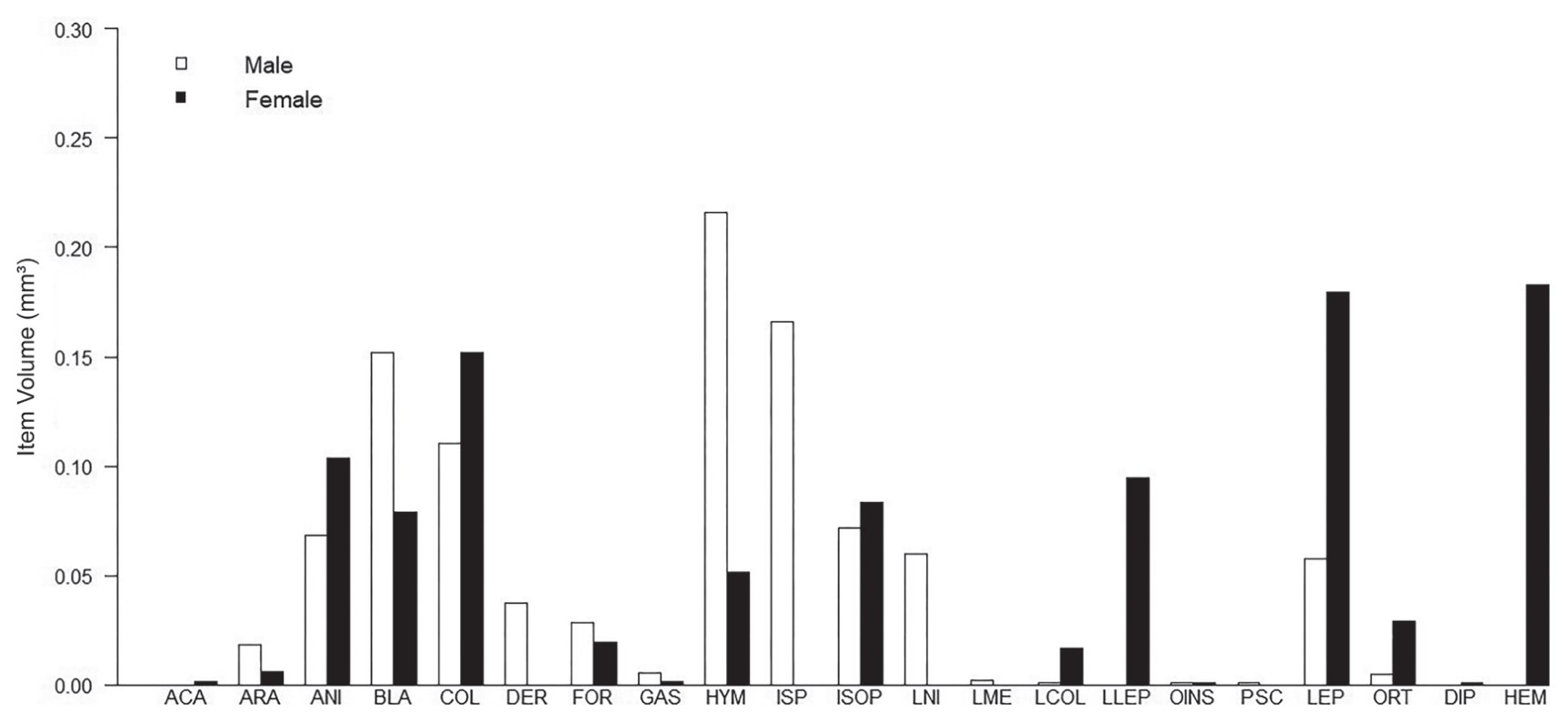

Figure 2. Proportion in volume for each prey category consumed by female and male Colobosauroides cearensis collected in this study. ACA, Acari; ARA, Aranae; ANI, Arthropode unidentified; BLA, Blattodea; COL, Coleoptera; DER, Dermaptera; FOR, Formicidae; HYM, Hymenoptera; ISO, Isoptera; ISOP, Isopoda; LNI, Larvae unidentified, LME, Larvae Mecoptera, LCOL, Larvae Coleoptera; LLEP, Larvae Lepidoptera; OINS, Insect egg; PSC, Pseudoscorpiones; LEP, Lepidoptera; ORT, Orthoptera; DIP, Diptera, HEM, Hemiptera.

estimated with the ellipsoid formula. Pearson and Spearman correlations were used to test whether there is correlation between the volume of eggs and SVL in females and testicular volume and SVL in males.

All statistical analyses were conducted on an $\mathrm{R}$ platform, version 2.15.0 (R Development Core Team 2017).

\section{Results}

Diet

We analyzed stomach contents of 120 individual lizards (61 adult females, 45 adult males and 14 juveniles), of which $3.5 \%(N=4)$ had empty stomachs. We identified 21 prey categories varying in frequency from 0.3 (Diptera) to 18.4 (Formicidae). The most common items are Hymenoptera (Formicidae included) (18.7), Isoptera (14.4), and unidentified insect larvae (7.6) (Table 1). The numerical niche width calculated from Simpson's Reciprocal Index is 5.52 and volumetric width is
9.2. Females have more prey categories $(N=$ 20), with Formicidae being the most important prey category (17.4). The diet of males consists of 15 taxa, among which Isoptera has the highest index of relative importance (20.4). Females have greater numerical and volumetric niche widths (4.92 and 8.44, respectively) than males (3.53 and 7.47, respectively). The niche overlap between the sexes is 0.6 and the dietary dissimilarity $30 \%$ (Figure 2).

\section{Sexual Dimorphism}

The smallest female lizard examined has a SVL of $22.21 \mathrm{~mm}$, whereas the smallest male is $26.74 \mathrm{~mm}$ long. Mean values, standard deviations, and ranges for each morphological variable are listed in Table 2. Males are significantly larger than females $(t$-test: $\mathrm{t}=$ -2.2119; $p=0.02937$ ) (Figure 3). Body shape (mean of pooled morphological variables $\mathrm{HH}$, TL, HW, and JL) differs significantly between sexes (MANOVA; $F=3.23, p>0.002$ ) (Figure 4). Males have six femoral pores (4 preanal and 
Table 1. Frequency $(F, \%)$, number $(N, \%)$, volume $(\mathrm{V}, \%)$, and Index of Relative Importance (IRI of each prey category in the diets of male and female Colobosauroides cearensis collected in area of Caatinga in Ceará state, Brazil.

\begin{tabular}{|c|c|c|c|c|c|c|c|c|c|c|c|c|}
\hline \multirow[t]{2}{*}{ Prey category } & \multicolumn{4}{|c|}{ General } & \multicolumn{4}{|c|}{ Females } & \multicolumn{4}{|c|}{ Males } \\
\hline & $F \%$ & $N \%$ & $\vee \%$ & IRI & $F \%$ & $N \%$ & $\vee \%$ & $|R|$ & $F \%$ & $N \%$ & $\vee \%$ & IRI \\
\hline \multicolumn{13}{|l|}{ Arachnida } \\
\hline Acari & 1.4 & 4.2 & 0.07 & 1.9 & 1.6 & 0.58 & 0.06 & 0.76 & - & - & - & - \\
\hline Aranae & 3.3 & 1.4 & 1.4 & 2.0 & 4.0 & 1.7 & 1.5 & 2.4 & 1.4 & 0.5 & 1.8 & 1.2 \\
\hline Pseudoscorpiones & 0.9 & 0.2 & 0.1 & 0.4 & - & - & - & - & 1.4 & 0.5 & 0.06 & 0.6 \\
\hline \multicolumn{13}{|l|}{ Insecta } \\
\hline Blattodea & 13.0 & 4.2 & 3.6 & 6.9 & 11.3 & 3.6 & 3.3 & 6.1 & 17.1 & 7.4 & 3.4 & 9.3 \\
\hline Coleoptera & 11.4 & 4.2 & 3.8 & 6.5 & 12.1 & 3.8 & 2.1 & 6.1 & 12.8 & 6.9 & 6.8 & 8.9 \\
\hline Dermaptera & 0.4 & 0.1 & 12.7 & 4.4 & 1.6 & 0.3 & 12.9 & 4.9 & - & - & - & - \\
\hline Diptera & 0.5 & 0.1 & 0.2 & 0.3 & 0.8 & 0.1 & 0.2 & 0.4 & - & - & - & - \\
\hline Formicidae & 28.7 & 26.0 & 0.3 & 18.4 & 27.6 & 33.7 & 0.3 & 17.2 & 24.2 & 31.0 & 0.3 & 18.5 \\
\hline Hemiptera & 1.4 & 0.3 & 6.9 & 2.9 & 0.8 & 0.1 & 16.8 & 5.9 & 2.8 & 1.0 & 10.7 & 4.9 \\
\hline Hymenoptera & 3.3 & 1.0 & 11.8 & 5.4 & 4.0 & 1.1 & 17.5 & 7.6 & 2.8 & 1.0 & 7.6 & 3.8 \\
\hline Isoptera & 16.7 & 25.0 & 1.1 & 14.4 & 15.4 & 21.4 & 1.2 & 12.7 & 17.1 & 41.7 & 1.3 & 20.0 \\
\hline Lepidoptera & 2.4 & 1.0 & 11.4 & 4.9 & 1.6 & 0.3 & 16.1 & 6.0 & 4.2 & 3.2 & 8.8 & 5.4 \\
\hline Orthoptera & 0.9 & 0.2 & 9.0 & 3.4 & 0.8 & 0.1 & - & 0.3 & 1.4 & 0.5 & 8.1 & 3.4 \\
\hline Insect egg & - & - & - & - & 0.8 & 0.1 & 0.005 & 0.3 & 1.4 & 0.5 & - & 1.0 \\
\hline \multicolumn{13}{|l|}{ Insecta Larvae } \\
\hline Coleoptera & 1.9 & 0.6 & 7.7 & 3.4 & 1.6 & 0.3 & 7.1 & 3.0 & 2.8 & 1.6 & 7.4 & 3.9 \\
\hline Lepidoptera & 0.9 & 0.2 & 5.4 & 2.2 & 0.8 & 0.1 & 0.07 & 0.3 & 1.4 & 0.5 & 26.8 & 9.6 \\
\hline Mecoptera & 1.4 & 5.1 & 0.1 & 2.2 & 2.4 & 7.7 & 0.1 & 3.4 & - & - & - & - \\
\hline Undetermined & 1.9 & 20.0 & 1.0 & 7.6 & 2.4 & 30.1 & 0.7 & 2.4 & 1.4 & 0.5 & 4.3 & 2.1 \\
\hline \multicolumn{13}{|l|}{ Crustacea } \\
\hline Isopoda & 0.9 & 0.5 & 17.4 & 6.3 & 1.6 & 0.7 & 17.6 & 6.6 & - & - & - & - \\
\hline $\begin{array}{l}\text { Undetermined } \\
\text { Arthropoda }\end{array}$ & 4.8 & 1.3 & 4.9 & 3.6 & 4.0 & 0.9 & 1.8 & 2.3 & 5.7 & 2.1 & 12.5 & 6.8 \\
\hline Mollusca & & & & & & & & & & & & \\
\hline Gastropoda & 2.3 & 1.2 & 0.3 & 1.3 & 4.0 & 1.9 & 0.8 & 2.2 & - & - & - & - \\
\hline
\end{tabular}


2 femoral) on each side; these are absent in juveniles and females. Within a population, the number of cloacal scales varies between four (19 females and 15 males) or five (41 females and 24 males).

\section{Microhabitat Use and Thermal Ecology}

We observed a total of 95 Colobosauroides cearensis exclusively in leaf litter inside caducifolious and subcaducifolious forests, with a spatial niche breadth of 1, thus indicating habitat specialization. No lizards were found in adjacent open areas with direct incidence of sunlight. The mean body temperature of the 95 specimens (54 females, 31 males and 10 juveniles) was $30.4 \pm 3.3^{\circ} \mathrm{C}\left(38.8-25.9^{\circ} \mathrm{C}\right)$. The mean substrate temperature was $28.1 \pm 3.8^{\circ} \mathrm{C}$ $\left(39.7-21^{\circ} \mathrm{C}\right)$; the air temperature was $28.1 \pm$ $4.25^{\circ} \mathrm{C}\left(37.7-21^{\circ} \mathrm{C}\right)$ and the air humidity was $66.4 \pm 8.5 \%(82-30.4 \%)$. Body temperature is positively correlated only with air temperature

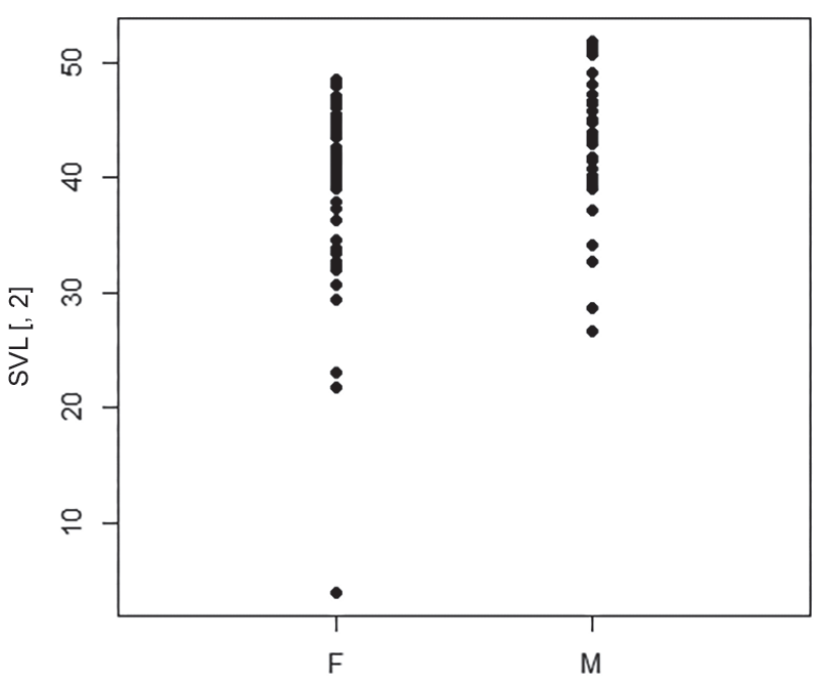

Figure 3. Result of $t$-test showing the variation in SVL between females (F) and males (M) of Colobosauroides cearensis.

$\left(R^{2}=0.1 ; p<0.008\right)$. There is no correlation between body temperature and substrate temperature $(p>0.1)$. Body temperature was significantly higher in the dry season $(31 \pm$
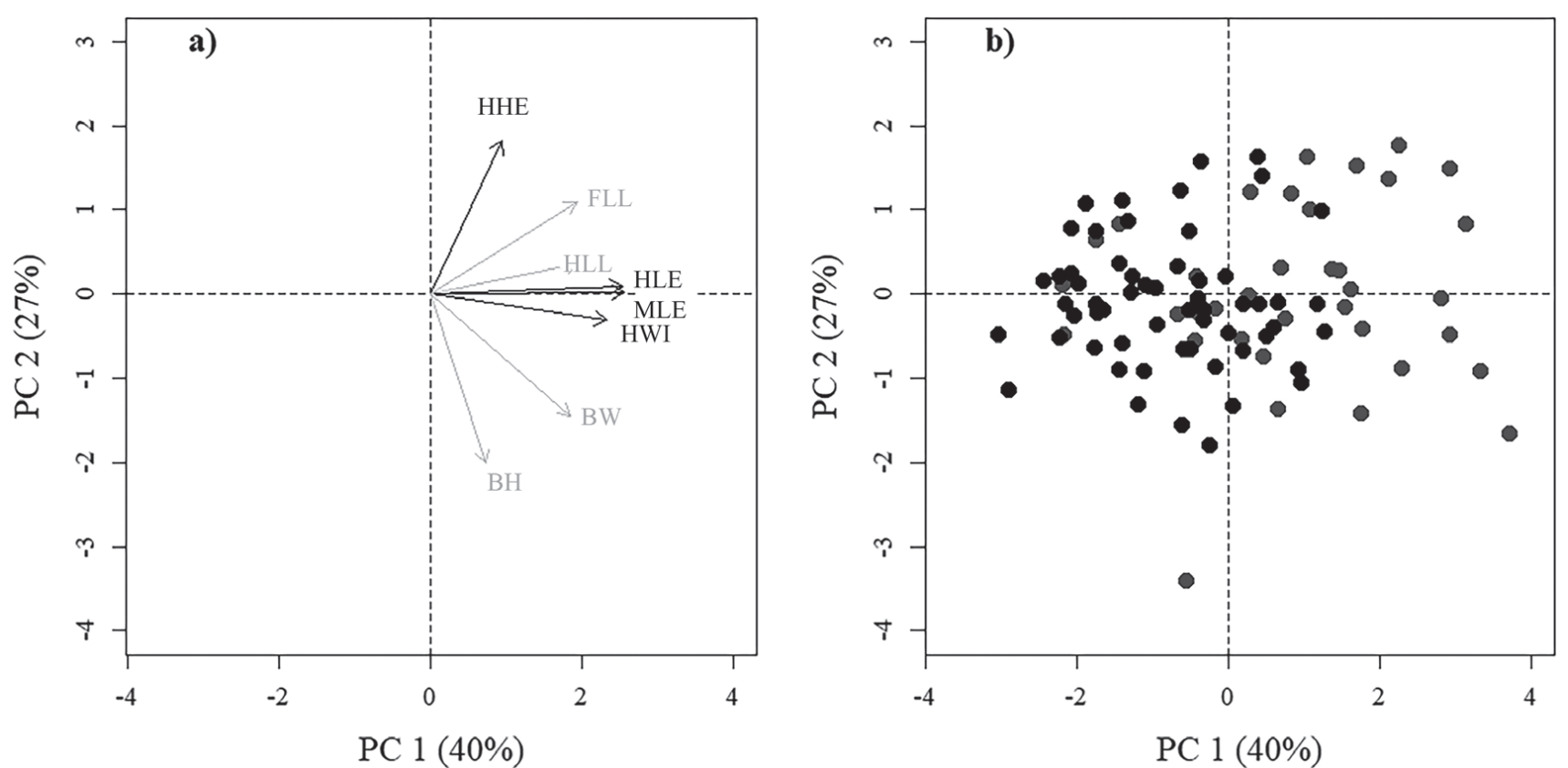

Figure 4. Results of PCA explained for two discriminant factors derived from morphometric variables for female and male Colobosauroides cearensis. (A) Black arrows indicate morphological characters accounting for sexual dimorphism. Head height (HHE), Head length (HLE), Head width (HWI), Mouth length (MLE), Body width (BW), Body height $(\mathrm{BH})$, Forelimb length (FLL), Hindlimb length (HLL). (B) Females (black circles) and males (gray circles). 
Table 2. Measurements of morphometric variables of Colobosauroides cearensis. Values (in mm) represent mean \pm standard deviation (range).

\begin{tabular}{lcc}
\hline Variable & \multicolumn{1}{c}{ Females } & Males \\
\hline Snout-vent length & $39.9 \pm 7.4(23.01-48.47)$ & $42.83 \pm 5.5(22.21-51.42)$ \\
Body width & $6.13 \pm 0.9(3.59-8.12)$ & $6.44 \pm 1.0(3.84-8.36)$ \\
Body height & $4.12 \pm 0.9(2.04-6.23)$ & $4.57 \pm 1.4(1.84-9.96)$ \\
Head width & $5.21 \pm 0.8(3.73-7.75)$ & $5.95 \pm 0.9(3.5-7.75)$ \\
Head height & $3.19 \pm 0.7(1.93-6.60)$ & $3.98 \pm 1.5(2.21-12.83)$ \\
Head length & $7.49 \pm 0.9(5.09-9.31)$ & $8.44 \pm 1.2(5.50-10.59)$ \\
Mouth length & $5.38 \pm 0.6(3.34-7.32)$ & $6.22 \pm 1.2(3.52-8.33)$ \\
Forelimb length & $6.8 \pm 0.8(4.72-9.2)$ & $7.43 \pm 1.1(5.26-9.98)$ \\
Hindlimb length & $11.5 \pm 1.3(7.39-14.86)$ & $12.27 \pm 1.3(7.57-14.65)$ \\
\hline
\end{tabular}

$\left.2.29^{\circ} \mathrm{C}\right)$ than in the rainy season $(T=-2.5003 ; p$ $=0.01)$. There were no intersexual differences in body temperature $(T=1.1 ; p=0.2)$ (Figure 5).

\section{Reproduction}

The SVL of the smallest reproductive female is $30.6 \mathrm{~mm}$, whereas that of the smallest reproductive male is $32.8 \mathrm{~mm}$. Females have a fixed clutch of two eggs $(N=8)$ being found in late December (beginning of rainy season). The mean egg volume is $96.13 \mathrm{~mm}^{3}$, and there is no relationship between mean egg volume and female SVL $(p=0.08)$ (Figure 6). Six females have eggs and vitellogenic follicles, thereby indicating that they produce more than one clutch during the reproductive season. Testicular volumes $\left(6.1 \pm 1.5 \mathrm{~mm}^{3}\right)$ are positively correlated with male SVLs $(R h o=0.4, p<0.001$; Figure 7 ), but there is no relationship between male reproductive activity and the season. The presence of juveniles between late December and May suggests that recruitment may occur early in the rainy season.

\section{Discussion}

Diet

Like other gymnophthalmids, Colobosauroides cearensis feeds on a variety of small arthropods (Doan 2008, Oliveira and Pessanha 2013, Garda et al. 2014, Oliveira et al. 2018); however, there are interspecific differences of the relative importance of prey consumed. Thus, Leposoma scincoides Spix, 1825 consumes primarily Aranae and Isopoda, whereas Micrablepharus maximiliani (Reinhardt and Lütken, 1862) prefers Orthoptera and Blattaria (Teixeira and Fonseca 2003, Dal Vechio et al. 2014). These dietary differences between species may reflect prey availability (Teixeira and Fonseca 2003, Mesquita et al. 2006).

Colobosauroides cearensis feeds on both sedentary and active prey, as do other species of the Ecpleopodini tribe (Teixeira and Fonseca 2003, Maia et al. 2011, Oliveira et al. 2018). However, the higher rate of ant consumption in C. cearensis is unexpected, because the 
frequency of Formicidae usually is low in gymnophthalmids, indicating that ants are a relatively unimportant part of their diets (Mesquita et al. 2006, Doan 2008, Anaya-Rojas et al. 2010, Maia et al. 2011, Santos et al. 2012, Oliveira and Pessanha 2013, Dal Vechio et al. 2014, Oliveira et al. 2018). Ants are avoided by most lizards, owing to the harder exoskeletons and wide range of defense mechanisms of ants (Abensperg-Traun and Csiro 1997). Sit-and-wait lizards usually eat the most ants (Colli et al. 1997). In Scleroglossa, the reduced consumption of ants may be associated with the presence of the toxic compounds they produce (Vitt et al. 2003, Japiassu et al. 2007). Two other gymnophthalmids, Anotosaura vanzolinia Dixon, 1974 and Dryadosaura nordestina Rodrigues, Xavier-Freire, Machado Pellegrino, and Sites, 2005 (Oliveira and Pessanha 2013, Garda et al. 2014) also consume ants at high rates, similar data were observed in. This dietary pattern may have a phylogenetic signal (Mesquita et al. 2016) because all three species belong to the subfamily Ecpelopodinae (Castoe et al. 2004). Thus, further investigation is merited to infer the phylogenetic significance of this

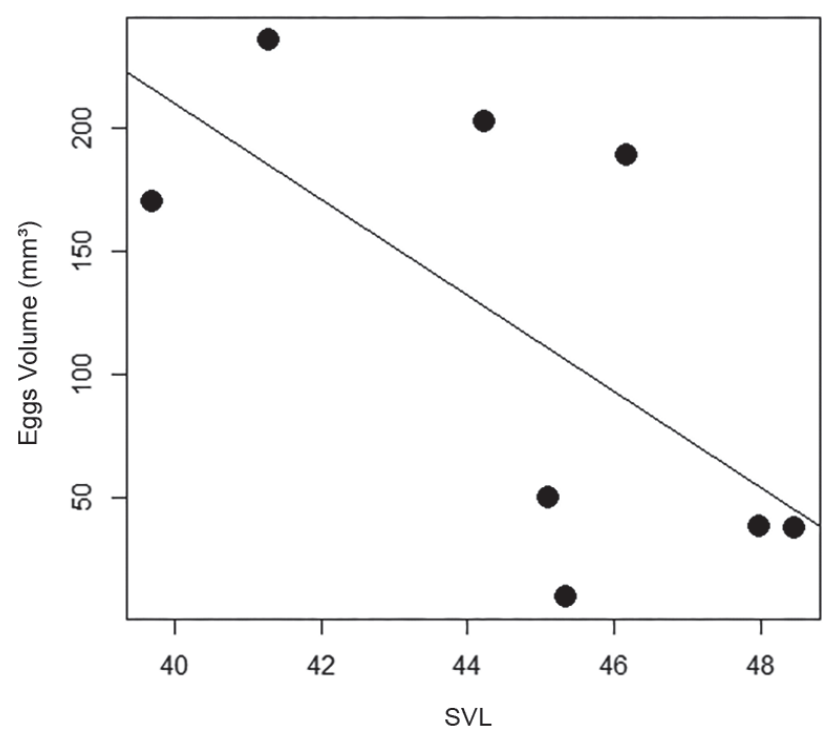

Figure 6. Relation between egg volume and female body size (SVL) of Colobosauroides cearensis.

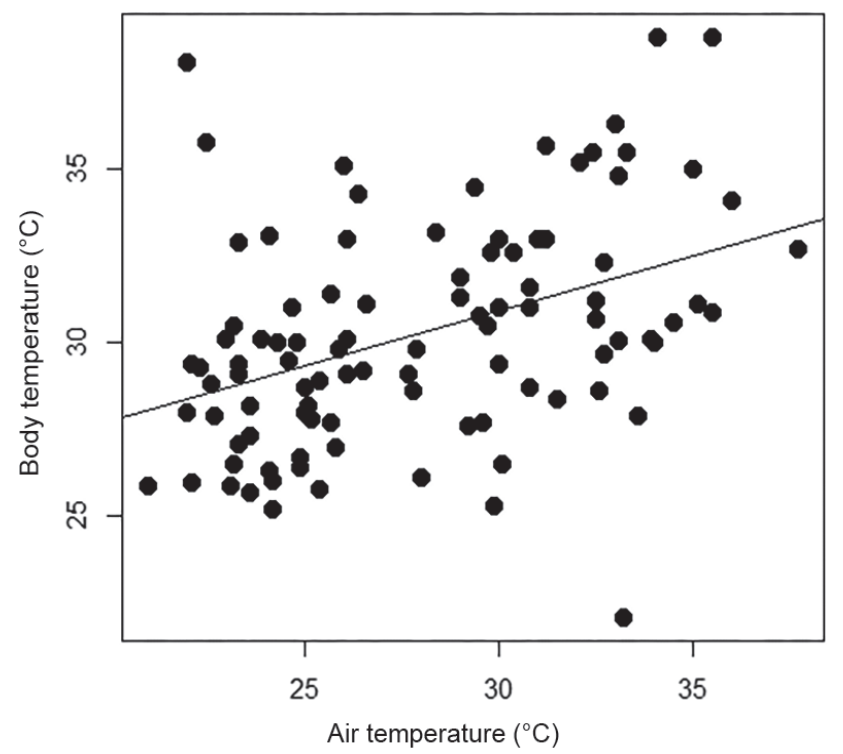

Figure 5. Correlation between the body temperature and air temperature in Colobosauroides cearensis.

foraging pattern of these species and that of other closely related taxa.

Isoptera, of which there is a high density and abundance in the Caatinga, is the second most important item in the diet of Colobosauroides cearensis; the prevalence of isopterans is related

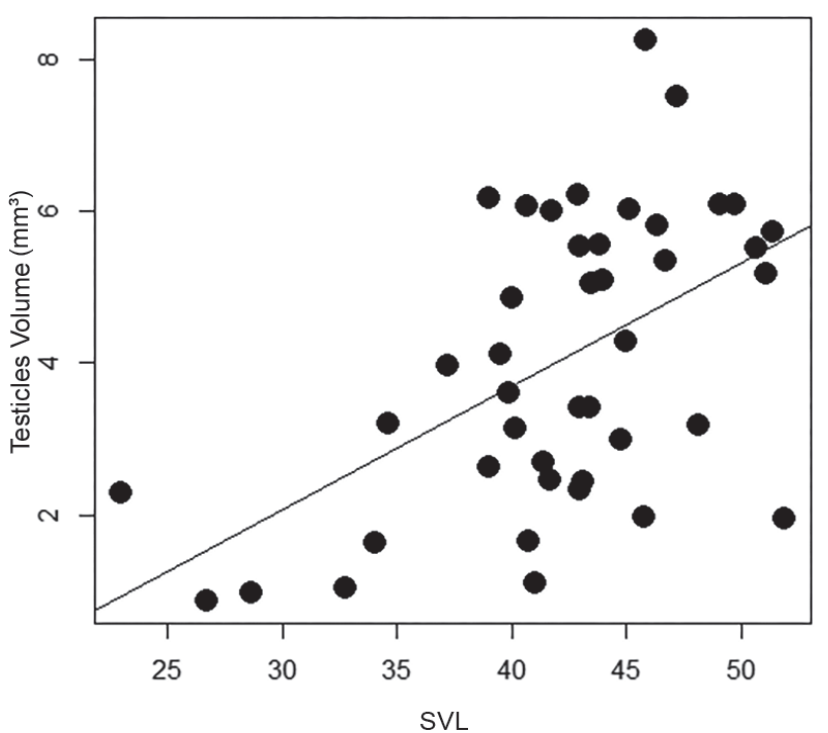

Figure 7. Relationship between testicular volume and male body size (SVL) of Colobosauroides cearensis. 
to the Caatinga's geomorphological characteristics that favor the structure of termite nests (Araújo et al. 2010). The presence of insect larvae in the diet is a common feature of $C$. cearensis, as well as other gymnophthalmids (Teixeira and Fonseca 2003, Rodrigues and Ávila-Pires 2005, Santos et al. 2012, Oliveira and Pessanha 2013). Active foragers usually consume sedentary prey in contrast to sit-and-wait foragers that primarily consume active prey (Colli et al. 1997).

The dietary niche breadth of Colobosauroides cearensis is similar to that of other gymnophthalmids that inhabit open vegetation biomes, such as Micrablepharus maximiliani and Colobosaura modesta (Reinhardt and Lütken, 1862) in Cerrado, which have niche breadth values of 5.0 and 4.0, respectively (Mesquita et al. 2006, Dal Vechio et al. 2014), and Anotosaura vanzolinia in Caatinga with 5.26 (Oliveira et al. 2018). The dietary niche breadth of female $C$. cearensis is greater than that of males; this difference may reflect the energy that females require during egg production and maintenance (Shine 1980, Shine and Schwarzkopf 1992).

\section{Sexual Dimorphism}

Sexual size dimorphism is typical of Gymnophthalmidae, with females being larger than males (Fitch 1981, Balestrin et al. 2010, Garda et al. 2014, Dal Vechio et al. 2014, Ramiro et al. 2017). In C. cearensi, however, males are larger than females, corroborating the results of Ramos-Pallares et al. (2010) for Ptychoglossus bicolor (Werner, 1916). This may be because at sexual maturity, the growth rate diminishes in both sexes owing to energy invested in reproduction (Fitch 1981). In some lizards, the growth rate of females decreases as the lizard invests energy in the production of gametes, whereas males invest little energy in reproduction and continue to grow (Smith and Ballinger 1994, Van Sluys 1998).

Sexual differences in head dimensions suggest that like Anotosaura vanzolinia and Dryadosaura nordestina, Colobosauroides cearensis is territorial (Vitt et al. 2003, Oliveira and Pessanha 2013, Garda et al. 2014). Anderson and Vitt (1990) reported that individuals with larger heads are more efficient during agonistic interactions in territorial defense. In contrast, in Calyptommatus leiolepis Rodrigues, 1991, Nothobachia ablephara Rodrigues, 1984, and Procellosaurinus tetradactylus Rodrigues, 1991 closely related taxa to $C$. cearensis, there is no sexual dimorphism in head sizes and proportions (Ramiro et al. 2017).

Preanal and femoral pores in lizards produce reproductive chemical secretions (Peloso and Ávila-Pires 2010, Ramiro et al. 2017). Previously reported for Colobosauroides cearensis, the absence of pores in females was considered a sexually dimorphic trait (Cunha et al. 1991). Although pores usually are associated with males (Balestrin et al. 2010, Peloso and Avila-Pires 2010, Dal Vechio et al. 2014, Ramiro et al. 2017), in some species, they are also present in females (Rodrigues 1996, Diehl 2007, Peloso and Ávila-Pires 2010).

Interpopulational variation in cloacal scales has been documented for other populations of $C$. cearensis in the state of Ceará (Cunha et al. 1991). The presence of a triangular fifth cloacal plate in males was thought to be sexually dimorphic (Cunha et al. 1991). However, our data do not support this supposition; therefore, this feature varies variation should be considered only as interpopulational differences.

\section{Microhabitat Use and Thermal Ecology}

Colobosauroides cearensis inhabits shaded microhabitats in the Caatinga and prefers microenvironments with leaf litter and minimal direct exposure to sunlight (Borges-Nojosa and Caramaschi 2003, Rodrigues 2003, Silva-Neta et al. 2019). The lizard has a high fidelity to leaf litter (Vitt et al. 2003) in the same way that Anotosaura vanzolinia is nearly exclusive in its fidelity $(77 \%)$ to underground retreats (Oliveira and Pessanha 2013, Oliveira et al. 2018). Species such as $C$. cearensis that has restricted 
microhabitat preferences potentially risk serious impacts on their populations if disturbances in the vegetation result in a decrease in leaf litter thereby restricting the available microhabitat. Habitat disturbance also can increase solar incidence causing changes in microhabitat temperature (Vitt and Ávila-Pires 1998), which is considered the most influential environmental variable determining the occurrence of gymnophthalmids (Winck and Rocha 2012).

Body temperatures of Colobosauroides cearensis are higher than those of other gymnophthalmids, such as the Amazonian species Potamites $(=$ Neusticurus) ecpleopus (Cope, 1875) $\left(\mathrm{Tb}=27.6^{\circ} \mathrm{C}\right), \mathrm{P} .(=$ Neusticurus $)$ juruazensis (Ávila-Pires and Vitt, 1998) $(\mathrm{Tb}=$ $\left.26.4^{\circ} \mathrm{C}\right)$ and Ptychoglossus bicolor $\left(\mathrm{Tb}=23.9^{\circ} \mathrm{C}\right)$ (Vitt and Ávila-Pires 1998, Anaya-Rojas et al. 2010). The body temperatures of 17 Amazonian gymnophthalmids, ranged from $23-33^{\circ} \mathrm{C}$ (DieleViegas et al. 2018); the latter authors attributed the higher body temperatures of $C$. cearensis to local environmental conditions, observing that open-habitat species tend to operate with higher temperatures. Despite their phylogenetic affinities of these taxa, body temperatures can vary depending on the environments and microclimates utilized by the species (Kohlsdorf and Navas 2006). Other factors, such as foraging behavior, are also related to active body temperature; thus, Scleroglossa (active foragers) usually have a higher average body temperature than does Iguania (Bergallo and Rocha 1994, Magnusson and Silva 1993).

The body temperature of $C$. cearensis is correlated with air temperature, as it is in other highly active lizards (Rocha and Bergalo 1990, Bergalo and Rocha 1993). Few heliothermic organisms maintain a slightly higher body temperature than that of the environment (Vitt and Ávila-Pires 1998, Anaya-Rojas et al. 2010). Furthermore, small-bodied lizards such as gymnophthalmids have high rates of water loss in relation to their small size; thus, they have a greater capacity for heat absorption (Steinberg et al. 2007).
The similarity of male and female body temperatures in C. cearensis indicates an absence of differential resource use. Thus, specimens sharing the same microenvironment have similar body temperature when active (Vitt and ÁvilaPires 1988). The seasonal variation found in cloacal temperatures can be influenced by habitat type (Sousa and Freire 2011). Because temperatures in the Caatinga Domain are lower during the rainy season, it is expected that body temperatures change seasonally (Leal et al. 2003).

Thermoregulation in Gymnophthalmidae varies according to microhabitat and environment with which the lizard is associated (Vitt and Ávila-Pires 1998, Diele-Viegas et al. 2018). In spite of inhabiting a region composed predominantly by Caatinga vegetation, $C$. cearensis occurs in shaded areas. Typically, forest lizards use small gaps among the leaves to expose their bodies to solar radiation for heat gain (Vitt and Ávila-Pires 1998, Vitt et al. 2003, Anaya-Rojas et al. 2010). However, none of the lizards we collected was observed to be exposed directly to the sun or even in small patches of light, evidencing a certain degree of thermoconforming (Hertz 1992, Bujes and Verrastro 2008, Ribeiro et al. 2008).

\section{Reproduction}

Commonly in lizards the size of the clutch is proportional to female body size (Winck and Rocha 2012). However, female body size in $C$. cearensis has no relationship to cluthch size, as also reported for Dryadosaura nordestina, Calyptommatus leiolepis, Nothobachia ablephara and Procellosaurinus tetradacytlus in Atlantic Forest and Caatinga in Northeastern Brazil (Garda et al. 2014, Ramiro et al. 2017). However, these results may be an evolutionary indication that the species achieved a balance between egg size and size of hatchlings, retaining its body dimensions (Adamopoulou and Valakos 2000).

Fixed clutchs of two eggs, along with presence of eggs and secondary follicles, are 
typical of Gymnophthalmidae (Teixeira and Fonseca 2003, Balestrin et al. 2010, Dal Vechio et al. 2014, Garda et al. 2014, Ramiro et al. 2017). To minimize the demographic effect caused by small clutches, species develop different strategies to optimize breeding patterns; multiple spawning throughout the year may favor stable population size (Teixeira and Fonseca 2003, Balestrin et al. 2010, Dal Vechio et al. 2014, Garda et al. 2014, Ramiro et al. 2017).

Unpredictability of the rainfall in the Caatinga (Reis 1976, Chiang and Koutavas 2004) may be correlated with continuous reproduction. If reproduction is concentrated in a single period, which at some point, may not provide favorable conditions for the performance of physiological activities, the existence of these organisms may be compromised (Garda et al. 2012).

Like other gymnophthalmids, reproduction of $C$. cearensis coincides with the beginning of the rainy season (Balestrin et al. 2010, Dal Vechio et al. 2014, Ramiro et al. 2017). According to Mesquita et al. (2006) this timing assures a greater availability of resources that would favor the development of the hatchlings. Decrease in mean temperature during rainy season in the Caatinga also may also be related to this reproductive pattern (Leal et al. 2003). According to Wiederhecker (1999), some lizards begin their reproductive cycles in times with lower temperatures and higher humidity, reducing the losses caused by desiccation; this seems to be true for $C$. cearensis, given the dependence of this species on a constant air temperature.

The minimum size of the sexually mature male of Colobosauroides cearensis $(32.8 \mathrm{~mm}$ SVL) is consistent with those of Cercosaura schreibersii Wiegmann, 1834 (25.9 mm SVL), Vanzosaura multiscutata (Amaral, 1933) (25.4 $\mathrm{mm}$ ), V. rubricauda (Boulenger, 1902) (25.8 $\mathrm{mm}$ SVL), and Dryadosaura nordestina (31.2 mm SVL) (Balestrin et al. 2010, Garda et al. 2014). These species may have may mature sexually in the first months of life. In contrast, the lizards Calyptommatus leiolepis $(45.0 \mathrm{~mm}$ SVL), Nothobachia ablephara (37.3 mm SVL), and Pholidobolus montium (Peters, 1863) (37.0 $\mathrm{mm}$ SVL) mature later than $C$. cearensis (Goldberg 2009, Ramiro et al. 2017). According to Tinkle et al. (1970), species that mature early have lower life expectancies; thus, that premature maturation allows multiple mating favoring the chances of producing offspring. In males, no clear pattern was observed regarding reproductive period and rainfall, suggesting that they are sexually active throughout the year (RamosPalhares et al. 2010). However, further histological studies of the testes should be performed to clarify this pattern.

The present study provides relevant ecological information about Colobosauroides cearensis, for which little was known about many aspects of the autecology, including habitat, diet, and distribution. These results will further the understanding not only of $C$. cearensis, but also the ecological patterns Gymnophthalmidae.

\section{Acknowledgments}

We are grateful to Conselho Nacional de Desenvolvimento Científico e Tecnológico$\mathrm{CNPq}$ for the research grant awarded to RWA (Process 303622/2015-6; 305988/2018-2). This study was financed in part by the Coordenação de Aperfeiçoamento de Pessoal de Nível Superior-Brasil (CAPES)_Finance code 001 for grant to AFSN.

\section{References}

Abensperg-Traun, M. and D. S. Csiro. 1997. Ant- and termite-eating in Australian mammals and lizards: a comparison. Australian Journal of Ecology 22: 9-17.

Adamopoulou, C. and E. D. Valakos. 2000. Small clutch size in a Mediterranean endemic lacertid (Podarcis milensis). Copeia 2000: 610-614.

Anaya-Rojas, J. M., V. H. Serrano-Cardozo, and M. P. Ramírez-Pinilla. 2010. Diet, microhabitat use, and thermal preferences of Ptychoglossus bicolor 
(Squamata: Gymnophthalmidae) in an organic coffee shade plantation in Colombia. Papéis Avulsos de Zoologia 50: 159-166.

Anderson, R. A. and L. J. Vitt. 1990. Sexual selection versus alternative causes of sexual dimorphism in teiid lizards. Oecologia 84: 145-157.

Araújo, V. F. P., A. G. Bandeira, and A. Vasconcellos. 2010. Abundance and stratification of soil macroarthropods in a Caatinga forest in northeast Brazil. Brazilian Journal of Biology 70: 737-746.

Balestrin, R. L., L. H. Cappellari, and A. B. Outeiral. 2010. Reproductive biology of Cercosaura schreibersii (Squamata, Gymnophthalmidae) and Cnemidophorus lacertoides (Squamata, Teiidae) in Sul-Riograndense Shield, Brazil. Biota Neotropica 10: 131-139.

Bergallo, H. G. and C. F. D. Rocha. 1994. Spatial and trophic niche differentiation in two sympatric lizards (Tropidurus torquatus and Cnemidophorus ocellifer) with different foraging tactics. Australian Journal of Ecology 19: 7275.

Borges-Nojosa, D. M. and U. Caramaschi. 2003. Composição e análise comparativa da diversidade e das afinidades biogeográficas dos lagartos e anfisbenídeos (Squamata) dos brejos Nordestinos. Pp. 181-236 in I. R. Leal, M. Tabarelli, and J. M. C. Silva (eds.), Ecologia $e$ Conservação da Caatinga. Recife. Editora Universitária, Universidade Federal de Pernambuco.

Bujes, C. S. and L. Verrastro. 2008. Annual activity of the lizard Liolaemus occipitalis (Squamata, Liolaemidae) in the coastal sand dunes of southern Brazil. Iheringia, Série Zoologia 98: 156-160.

Castoe, T. A., T. M. Doan, and C. L. Parkinson. 2004. Data partitions and complex models in Bayesian analysis: the phylogeny of gymnophthalmid lizards. Systematic Biology 53: 448-469.

Chiang, J. C. H. and A. Koutavas. 2004. Tropical Flip-Flop connections. Nature 432: 684-685.

Colli, G. R., D. O. Mesquita, P. V. V. Rodrigues, and K. Kitayama. 2003. Ecology of the gecko Gymnodactylus geckoides amarali in a Neotropical savanna. Journal of Herpetology 37: 694-706.

Colli, G. R., A. K. Péres, M. G. Zatz, and A. C. S. Pinto. 1997. Estratégias de forrageamento e dieta em lagartos do cerrado e savanas amazônicas. Pp. 219-231 in L. L. Leite and C. H. Saito (eds.), Contribuição ao Conhecimento Ecológico do Cerrado. Brasília. Departamento de Ecologia Publishing, Universidade de Brasília.
Cunha, O. R., J. S. Lima-Verde, and A. C. M. Lima. 1991. Novo gênero e espécie de lagarto do estado do Ceará (Lacertilia: Teiidae). Boletim do Museu Paraense Emílio Goeldi, Série Zoologia 7: 163-176.

Dal Vechio, F., R. Recoder, H. Zaher, and M. T. Rodrigues. 2014. Natural history of Micrablepharus maximiliani (Squamata: Gymnophthalmidae) in a Cerrado region of northeastern Brazil. Zoologia 31: 114-118.

Diele-Viegas, L. M., L. J. Vitt, B. Sinervo, G. R. Colli, F. P. Werneck, D. B. Miles, W. E. Magnusson, J. C. Santos, C. M. Sette, G. H. O. Caetano, E. Pontes, and T. C. S. Ávila-Pires. 2018. Thermal physiology of Amazonian lizards (Reptilia: Squamata). PLoS ONE 13: 3.

Doan, T. M. 2008. Dietary variation within the Andean lizard clade Proctoporus (Squamata: Gymnophthalmidae). Journal of Herpetology 42: 16-21.

Dunham, A. E., D. B. Miles, and D. N. Reznick. 1988. Life history patterns in squamate reptiles. Pp. 441-522 in C. Gans and R. B. Huey (eds.), Biology of the Reptilia. New York. Alan R. Liss, Inc.

Fitch, H. S. 1981. Sexual size differences in reptiles. Miscellaneouse Publications, Museum of Natural History, University of Kansas 70: 1-72.

Garda, A. A., P. H. Medeiros, M. B. Lion, M. R. De Brito, G. H. Vieira, and D. O. Mesquita. 2014. Autoecology of Dryadosaura nordestina (Squamata: Gymnophthalmidae) from Atlantic forest fragments in northeastern Brazil. Zoologia 31: 418-425.

Garda, A. A., G. C. Costa, F. G. França, L. G. Giugliano, G. S. Leite, D. O. Mesquita, C. Nogueira, L. TavaresBastos, M. M.Vasconcellos, G. H. C. Vieira, L. J. Vitt, F. P. Werneck, H. C. Wiederhecker, and G. R. Colli. 2012. Reproduction, body size, and diet of Polychrus acutirostris (Squamata: Polychrotidae) in two contrasting environments in Brazil. Journal of Herpetology 46: 2-8.

Goldberg, S. R. 2009. Note on reproduction of Pholidobolus montium (Squamata: Gymnophthalmidae) from Ecuador. Bulletin of the Chicago Herpetological Society 44: $167-168$.

Gotelli, N. and G. Entsminger. 2004. EcoSim. Null Modeling Software for Ecology. Version 7. Acquired Intelligence Inc. and Kesey-Bear. Jericho. VT 05465. URL: http:// www.garyentsminger.com/ecosim/index.htm.

Gower, J. C. 1966. Some distance properties of latent root and vector methods used in multivariate analysis. Biometrika 53: 325-338.

Hertz, P. E. 1992. Temperature regulation in Puerto Rican Anolis lizards: a field test using null hypotheses. Ecology 73: 1405-1417. 
Huey, R. B., E. R. Pianka, and T. W. Schoener (eds.). 1983. Lizard Ecology: Studies of a Model Organism. Cambridge. Harvard University Press. 501 pp.

IPECE. Instituto de Pesquisa e Estratégia Econômicas do Ceará. 2016. Ceará em números 2016: an online Reference. Eletronic Database acessible at: http:// www2.ipece.ce.gov.br/publicacoes/ceara_em_ numeros/2016/teritorial/index.htm Captured on 12 November 2017.

IUCN. International Union for Conservation of Nature. 2017. An online Reference. Eletronic Database acessible at: https://www.iucn.org/. Captured on 12 March 2017.

Japiassu, R., R. Constantino, and G. Colli. 2007. Cupins na dieta de lagartos: seleção de presa por defesa química. Caxambu, MG. Anais do VIII Congresso de Ecologia do Brasil.

Kohlsdorf, T. and C. A. Navas. 2006. Ecological constraints on the evolutionary association between field and preferred temperatures in Tropidurinae lizards. Evolutionary Ecology 20: 549-564.

Leal, I. R., M. Tabarelli, and J. M. C. Silva. (eds.). 2003. Ecologia e Conservação da Caatinga. Recife. Editora Universitária, Universidade Federal de Pernambuco. 822 pp.

Magnusson, W. E. and E. V. Silva. 1993. Relative effects of size, season and species on the diets of some Amazonian savanna lizards. Journal of Herpetology 27: 380-385.

Maia, T., M. Almeida-Gomes, C. C. Siqueira, D. Vrcibradic, M. C. Kiefer, and C. F. D. Rocha. 2011. Diet of the lizard Ecpleopus gaudichaudii (Gymnophthalmidae) in Atlantic Rainforest, state of Rio de Janeiro, Brazil. Zoologia 28: 587-592.

Mesquita, D. O., G. C. Costa, and G. R. Colli. 2006. Ecology of an Amazonian savanna lizard assemblage in Monte Alegre, Pará state, Brazil. South American Journal of Herpetology 1: 61-71.

Mesquita, D. O., G. C. Costa, G. R. Colli, T. B. Costa, D. B. Shepard, L. J. Vitt, and E. R. Pianka. 2016. Life-History Patterns of Lizards of the World. American Naturalist 187: 689-705.

Myers, N., R. A. Mittermeier, C. G. Mittermeier, G. A. B. Fonseca, and J. Kent. 2000. Biodiversity hotspots for conservation priorities. Nature 403: 853-858.

Oliveira, B. H. S. D. and A. L. M. Pessanha. 2013. Microhabitat use and diet of Anotosaura vanzolinia (Squamata: Gymnophthalmidae) in a Caatinga area, Brazil. Biota Neotropica 13: 193-198.
Oliveira, B. H. S., R. N. M. Queiroz, L. B. Q. Cavalcanti, and D. O. Mesquita. 2018. Autecology of neotropical lizard species Anotosaura vanzolinia (Squamata, Gymnophthalmidae) in a Caatinga region, north-eastern Brazil. Herpetological Journal 28: 19-26.

Pellegrino, K. C. M., M. T. Rodrigues, Y. YonenagaYassuda, and F. W. Sites Jr. 2001. A molecular perspective on the evolution of microteiid lizards (Squamata, Gymnophthalmidae), and a new classification for the family. Biological Journal of the Linnean Society 74: $315-338$.

Peloso, P. L. and T. C. Ávila-Pires. 2010. Morphological variation in Ptychoglossus brevifrontalis Boulenger, 1912 and the status of Ptychoglossus nicefori (Loveridge, 1929) (Squamata, Gymnophthalmidae). Herpetologica 66: $357-372$.

Pianka, E. R. 1973. The structure of lizard communities. Annual Review of Ecology and Systematics 4: 53-74.

Pianka, E. R. and L. J. Vitt (eds.). 2003. Lizards: Windows to the Evolution of Diversity. Berkeley. University of California Press. 333 pp.

Powell, R., J. S. Parmelee, M. A. Rice, and D. D. Smith. 1990. Ecological observations of Hemidactylus brookihaitianus Meerwath (Sauria: Gekkonidae) from Hispaniola. Caribbean Journal of Science 26: 67-70.

Primack, R. A (eds.). 2008. Primer of Conservation Biology. Sunderland. Sinauer Associates Press. 293 pp.

Ramiro, C. N., M. T. Júnior, and M. T. Rodrigues. 2017. Reproductive biology of three sympatric species of Gymnophthalmid lizards from the San Dunes of the middle São Francisco River, Bahia, Brazil. South American Journal of Herpetology 12: 76-88.

Ramos-Pallares, E., V. H. Serrano-Cardozo, and M. P. Ramirez-Pinilla. 2010. Reproduction of Ptychoglossus bicolor (Squamata: Gymnophthalmidae) in an Andean coffee shade plantation in Colombia. South American Journal of Herpetology 5: 143-150.

R Development Core Team. 2017. R. A language and environment for statistical computing. R Foundation for Statistical Computing, Vienna, Austria. Version 2.15.0. URL: https://www.R-project.org.

Reis, A. C. 1976. Clima da Caatinga. Anais da Academia Brasileira de Ciências 48: 325-335.

Ribeiro, L. B., S. C. Gomides, A. O. Santos, and B. M. Sousa. 2008. Thermoregulatory behavior of the saxicolous lizard, Tropidurus torquatus (Squamata: Tropiduridae), in a rocky outcrop in Minas Gerais, Brazil. Herpetological Conservation and Biology 3: 63-70. 
Rocha, C. F. D. and H. G. Bergallo. 1990. Thermal biology and flight distance of Tropidurus oreadicus (Sauria Iguanidae) in an area of Amazonian Brazil. Ethology Ecology and Evolution 2: 263-268.

Rocha, C. F. D., M. Van Sluys, D. Vrcibradic, M. C. Kiefer, V. A. Menezes, and C. C. Siqueira. 2009. Comportamento de termorregulação em lagartos brasileiros. Oecologia Brasiliensis 13: 115-131.

Rodrigues, M. T. 1996. A new species of lizard, genus Micrablepharus (Squamata: Gymnophthalmidae), from Brazil. Herpetologica 52: 535-541.

Rodrigues, M. T. 2003. Herpetofauna da Caatinga. Pp. 181236 in I. R. Leal, M. Tabarelli, and J. M. C. Silva (eds.), Ecologia e Conservação da Caatinga. Recife. Editora da Universidade Federal de Pernambuco.

Rodrigues, M. T. and T. C. S. Ávila-Pires. 2005. New lizards of the genus Leposoma (Squamata, Gymnophthalmidae) from the lower Rio Negro, Amazonas, Brazil. Journal of Herpetology 39: 541-546.

Rodrigues, M. T., K. C. M. Pellegrino, M. Dixo, V. K. Verdade, D. Pavan, A. J. S. Argolo, and J. W. Sites Jr. 2007. A new genus of microteiid lizard from the Atlantic forests of state of Bahia, Brazil, with a new generic name for Colobosaura mentalis, and a discussion of relationships among the Heterodactylini (Squamata, Gymnophthalmidae). American Museum Novitates 3565: 1-27.

Santos, M. V. G., I. G. S. Macedo, R. S. Sousa, M. Gogliath, and L. B. Ribeiro. 2012. Diet of Nothobachia ablephara (Squamata: Gymnophthalmidae) in a Caatinga area of the San Francisco Valley in northeastern Brazil. Herpetology Notes 5: 305-307.

Shine, R. 1980. "Costs" of reproduction in reptiles. Oecologia 46: $92-100$.

Shine, R. and L. Schwarzkopf. 1992. The evolution of reproductive effort in lizards and snakes. Evolution 46: $62-75$.

Silva, M. B., L. S. Carvalho, and V. Rodrigues. 2015. Reptiles in an ecotonal area in northern state of Piauí, Brazil. Boletim do Museu de Biologia Mello Leitão 37: 437-455.

Silva-Neta, A. F., T. F. Quirino, and C. S. L. Matias. 2019. Colobosauroides cearensis Cunha, Lima-Verde and Lima, 1991 (Squamata, Gymnophthalmidae): new record for the northeast of Brazil. Cuadernos de Herpetología 33: 49-50.

Smith, G. R. and R. E. Ballinger. 1994. Temporal and spatial variation in individual growth in the spiny lizard, Sceloporus jarroyi. Copeia 1994: 1007-1013.

Sousa, P. A. G. and E. M. X. Freire. 2011. Thermal ecology and thermoregulatory behavior of Coleodactylus natalensis (Squamata: Sphaerodactylidae), in a fragment of the Atlantic Forest of northeastern, Brazil. Zoologia 28: 693-700.

Steinberg, D. S., S. D. Powell, R. Powell, J. S. Paemerlee Jr., and R. W. Henderson. 2007. Population densities, Water-Loss rates, and diets of Sphaerodactylus vincenti on St. Vincent, West Indies. Journal of Herpetology 41: 330-336.

Teixeira, R. L. and F. R. Fonseca. 2003. Tópicos ecológicos de Leposoma scincoides (Sauria, Gymnophthalmidae) da região de Mata Atlântica de Santa Teresa, Espírito Santo, sudeste do Brasil. Boletim do Museu de Biologia Mello Leitão 15: 17-28.

Tinkle, D. W., H. M. Wilbur, and S. G. Tilley. 1970. Evolutionary strategies in lizard reproduction. Evolution 24: $55-74$.

Torgerson, W. S. 1958. Theory and Methods of Scaling, New York. Wiley. 460 pp.

Uetz, P. and J. Hošek. 2016. The Reptile Database. An online Reference. Eletronic Database acessible at: http:// www.reptiledatabase.org. Captured on 12 March 2017.

Van-Sluys, M. 1998. Growth and body condition of the saxicolous lizard Tropidurus itambere in southeastern Brazil. Jounal Herpetology 32: 359-365.

Vitt, L. J. and T. C. S. Ávila-Pires. 1998. Ecology of two sympatric species of Neusticurus (Sauria: Gymnophthalmidae) in the western Amazon of Brazil. Copeia 1998: 570-582.

Vitt, L. J. and J. P. Caldwell (eds.). 2013. Herpetology: An Introductory Biology of Amphibians and Reptiles. $4^{\text {th }}$ Edition. London and San Diego. Academic Press, Elsevier Inc. 757 pp.

Vitt, L. J. and E. R. Pianka (eds.). 1994. Lizard Ecology, Historical and Experimental Perspectives. Chicago. Princeton University Press. 416 pp.

Vitt, L. J., E. R. Pianka, W. E. Cooper Jr., and K. Schwenk. 2003. History and the global ecology of squamate reptiles. American Naturalist 162: 44-60.

Wiederhecker, H. C. 1999. Ciclo reprodutivo e demografia de Tropidurus torquatus (Squamata, Tropiduridae) no Cerrado do Brasil central. Unpublished PhD. Thesis. Universidade de Brasília, Brasil.

Winck, G. R. and C. F. D. Rocha. 2012. Reproductive trends of Brazilian lizards (Reptilia, Squamata): the relationship between clutch size and body size in females. North-Western Journal of Zoology 1: 57-62.

Editor: Steven Poe 